\title{
Safety and Efficacy of Intratracheal Recombinant Human Clara Cell Protein in a Newborn Piglet Model of Acute Lung Injury
}

\author{
SUDHISH CHANDRA, JONATHAN M. DAVIS, STEVEN DREXLER, JOLANTA KOWALEWSKA, \\ DARRIN CHESTER, HSHI-CHI KOO, SIMCHA POLLACK, RICHARD WELCH, \\ APRILE PILON, AND CAROLYN R. LEVINE
}

Cardiopulmonary Research Institute and Departments of Pediatrics [S.C., J.M.D., D.C., H.-C.K., C.R.L.], Pathology [S.D., J.K.], and Biostatistics [S.P.], Winthrop-University Hospital, SUNY Stony Brook School of Medicine, Mineola, New York 11501, U.S.A., and Claragen, Inc., Rockville, Maryland 20852, U.S.A.

[R.W., A.P.]

\begin{abstract}
Despite the widespread use of exogenous surfactant, acute and chronic lung injury continues to be a major cause of morbidity in preterm infants. CC10 is a protein produced by Clara cells that inhibits phospholipase $\mathrm{A}_{2}$ and has anti-inflammatory and antifibrotic properties. We studied whether intratracheal (IT) recombinant human Clara cell protein (rhCC10) could safely minimize lung injury in a newborn piglet model of acute lung injury. Twenty-nine newborn piglets were given Survanta and then ventilated for $48 \mathrm{~h}$ receiving the following: room air (group 1 ); $100 \% \mathrm{O}_{2}$ (group 2); or $100 \% \mathrm{O}_{2}$ and 25 , 5, or $1 \mathrm{mg} / \mathrm{kg}$ (groups 3, 4, and 5, respectively) of IT rhCC10 (diluted to 2 $\mathrm{mL} / \mathrm{kg}$ with saline) at time 0 . Laboratory studies, oxygen ratios, static pressure-volume curves, bronchoalveolar lavage (for inflammatory markers), and histologic analyses were performed over the 48-h study period. Pulmonary compliance and oxygenation were significantly improved in animals receiving $5 \mathrm{mg} / \mathrm{kg}$ IT rhCC10 compared with room air and $100 \% \mathrm{O}_{2}$ controls $(p<$ 0.004 and $p<0.05$, respectively, ANOVA). Reductions in
\end{abstract}

\section{ABSTRACT}

inflammatory markers were seen in animals receiving rhCC10, although changes did not reach statistical significance. No significant toxicity was noted. rhCC10 appeared safe and improved pulmonary function in this newborn piglet model of hyperoxic lung injury. We speculate that rhCC10 may represent a promising therapy for the prevention of lung injury in preterm infants.

(Pediatr Res 54: 509-515, 2003)

$\quad$ Abbreviations
BPD, bronchopulmonary dysplasia
BAL, bronchoalveolar lavage
rhCC10, recombinant human clara cell protein
IT, intratracheal
$\mathbf{O}_{2}$, oxygen
a/A ratio, arterial/alveolar oxygen ratios
NCA, neutrophil chemotactic activity
SPLA, secretory phospholipase $\mathrm{A}_{2}$

Bronchopulmonary dysplasia continues to be a significant problem for the preterm infant despite improvements in neonatal intensive care. Although the use of antenatal steroids and exogenous surfactant has resulted in decreased severity of $\mathrm{BPD}$, the prevalence of BPD in the preterm population has actually increased. BPD is a multifactorial disease process that is the end result of an immature, surfactant-deficient lung that has been exposed to hyperoxia, mechanical volutrauma, and infection. These forces initiate a cascade of pro-inflammatory

Received April 3, 2002; accepted March 6, 2003

Correspondence: Carolyn Robbins Levine, M.D., Department of Pediatrics, WinthropUniversity Hospital, 259 First Street, Mineola, New York 11501; U.S.A.; e-mail: clevine@winthrop.org

Supported by grant HL66965-02 from the National Heart, Lung, and Blood Institute, Bethesda, MD, U.S.A.

DOI: 10.1203/01.PDR.0000081300.49749.87 cytokines that lead to the development of significant inflammatory changes and chronic lung injury.

$\mathrm{CC} 10$ is produced by the nonciliated cells of the tracheobronchial epithelial tree and is thought to have numerous anti-inflammatory properties. It has been shown to play a significant role, both in vitro and in vivo, in modulating inflammation (1-5). CC10, also known as uteroglobin, inhibits $\operatorname{sPLA}_{2}(2,6)$, an enzyme that degrades surfactant and facilitates prostaglandin biosynthesis (through the cleavage of arachidonic acid from cell membrane phospholipids). In vitro, CC10 has been shown to inhibit neutrophil and phagocyte chemotaxis (3) and IL-stimulated release of numerous cytokines in human blood lymphocytes (tumor necrosis factor- $\alpha$, IL- $1 \beta$, and interferon- $\gamma$ ) (4). CC10 also inhibits the formation of the proinflammatory fibronectin/IgA complex that may mitigate fibrotic changes in the lung (7). Further in vivo evidence of these 
anti-inflammatory properties comes from transgenic mice deficient in CC10. Exposure of these mice to $100 \% \mathrm{O}_{2}$ results in earlier mortality as well as an accelerated pulmonary inflammatory response (8).

CC10 levels in tracheal aspirates of preterm babies have been shown to be 2- to 4-fold lower than in the mature newborn lung $(9,10)$. The appearance of CC10 in amniotic fluid dates from $16 \mathrm{wk}$ of gestation and production appears to be upregulated both as a function of gestational as well as postnatal age (11), in a timeline similar to that of pulmonary surfactant. Most recently, increased levels of oxidized $\mathrm{CC} 10$ and decreased immunoreactive Clara cell protein in tracheal aspirates of ventilated, preterm infants were shown to correlate with the development of BPD (12). We hypothesized that supplementation of CC10 might minimize the inflammatory and fibrotic changes that contribute to the development of BPD. We therefore evaluated the safety and efficacy of IT rhCC10 in minimizing acute inflammatory changes and lung injury in newborn piglets ventilated with $100 \% \mathrm{O}_{2}$ for $48 \mathrm{~h}$.

\section{METHODS}

Study design. Twenty-nine 1- to 3-d-old piglets were mechanically ventilated for $48 \mathrm{~h}$ and studied as follows: group 1 $(n=5)$ piglets were mechanically ventilated with $21 \% \mathrm{O}_{2}$ and received IT placebo ( $2 \mathrm{~mL} / \mathrm{kg}$ normal saline) at time 0 ; group 2 piglets $(n=5)$ were ventilated with $100 \% \mathrm{O}_{2}$ and received IT placebo at time 0 ; piglets in groups $3(n=6), 4(n=7)$, and $5(n=6)$ were ventilated with $100 \% \mathrm{O}_{2}$ and received 1,5 , or $25 \mathrm{mg} / \mathrm{kg}$ IT rhCC10 (Claragen, Inc. Rockville, MD, U.S.A.), respectively, at time 0 . Animals in all groups received $4 \mathrm{~mL} / \mathrm{kg}$ of surfactant (Survanta, Ross Laboratories, Columbus, OH, U.S.A.), 10-30 min before the administration of rhCC10. rhCC10 (diluted to a total volume of $2 \mathrm{~mL} / \mathrm{kg}$ with normal saline) was instilled with the piglets in a $30^{\circ}$ Trendelenberg (head-down) position in two divided doses in the left lateral and right lateral decubitus positions.

Recombinant human CC10 was produced in Escherichia coli bacteria according to published methods (6) and purified by a proprietary process (Claragen, Inc.). The protein for the study was provided as a $>98 \%$ pure solution of the human CC10 homodimer. The biologic activity of each batch was compared using a previously published secretory phospholipase $\mathrm{A}_{2}$ inhibition assay for rhCC10 (6). Dilutions of 5 $\mathrm{mg} / \mathrm{mL}$ rhCC10 stock for the $1 \mathrm{mg} / \mathrm{kg}$ dose groups were performed with sterile saline.

At the start of the experiment, the piglets were anesthetized with intraperitoneal pentobarbital sodium $(25-30 \mathrm{mg} / \mathrm{kg}$ ), placed on a heating blanket, intubated with a $3.5-4.0 \mathrm{~mm}$ endotracheal tube and a $3.5 \mathrm{~F}$ umbilical arterial line was inserted. Mechanical ventilation was begun using a Bear Cub infant ventilator (VIASYS Healthcare, Palm Springs, CA, U.S.A.) with positive end expiratory pressure of $3 \mathrm{~cm} \mathrm{H}_{2} \mathrm{O}$, inspiratory time $0.5 \mathrm{~s}$, and a flow rate of $8 \mathrm{~L} / \mathrm{min}$. Peak inspiratory pressure and ventilatory rate were varied to maintain partial pressure of carbon dioxide $\left(\mathrm{PaCO}_{2}\right)$ at $40-50$ torr. Blood gases were measured every 3-4 h using a Corning 238 blood gas analyzer (Medfield MA, U.S.A.). Five percent dex- trose with 0.33 normal saline was administered at $80 \mathrm{~mL} / \mathrm{kg} / \mathrm{d}$. Ampicillin $(50 \mathrm{mg} / \mathrm{kg})$ and gentamicin $(2.5 \mathrm{mg} / \mathrm{kg})$ were given every $12 \mathrm{~h}$ until the end of the experiment. Additional pentobarbital was administered as needed to maintain sedation (paralyzing agents were not needed). Serial blood counts with differentials and coagulation studies were monitored for potential side effects of rhCC10. Arterial/alveolar ratios were calculated on the last available ABG before sacrifice. All animal studies were approved by the Institutional Animal Care and Use Committee (IACUC) of Winthrop-University Hospital.

At the conclusion of the 48-h study period, piglets were given pentobarbital $(30 \mathrm{mg} / \mathrm{kg})$ and static pressure-volume curves were generated. The endotracheal tube was clamped for 5 min to allow for resorption atelectasis. The chest was opened and pressure-volume measurements obtained. The lung was inflated to $40 \mathrm{~cm} \mathrm{H}_{2} \mathrm{O}$ for $1 \mathrm{~min}$ and the volume recorded. The pressure was then decreased to $30,20,10,5$, and $0 \mathrm{~cm} \mathrm{H}_{2} \mathrm{O}$ and the volume recorded (after a 30-s stabilization period at each level). Volumes obtained were normalized for the weight of the animal.

The lungs were then removed en bloc, the right lung isolated and inflation fixed with $10 \%$ formalin at a constant pressure of $30 \mathrm{~cm} \mathrm{H}_{2} \mathrm{O}$ for further pathologic analysis. BAL was performed on the left lung with PBS $(3 \times 25 \mathrm{~mL})$. The BAL was immediately spun at $350 \times g$ to remove cellular debris. The cell pellet was resuspended in $5 \mathrm{~mL}$ of saline and the number of cells was determined using a Coulter Counter HEMO-W (Biodynamics, Edison, NJ, U.S.A.). Differential cell counts were performed after cytocentrifugation (Cytospin 2, Shandon Scientific, Pittsburgh, PA, U.S.A.) and Wright's staining. The supernatant was subjected to additional centrifugation at 5000 $\times g$ for $10 \mathrm{~min}$. A portion of the supernatant was concentrated 10 -fold by lyophilization and frozen at $-70^{\circ} \mathrm{C}$ for subsequent analysis.

NCA and biochemical assays. Neutrophils were isolated from unventilated control pigs as previously described (13). Forty milliliters of blood were placed in a $60-\mathrm{mL}$ syringe containing $4 \mathrm{~mL}$ acid citrate dextrose anticoagulant and $10 \mathrm{~mL}$ dextran, to agglutinate and sediment red blood cells. The white blood cell layer was drawn off and resuspended to a total of 35 $\mathrm{mL}$ in normal saline. Cells were sedimented at $350 \times \mathrm{g}$ for 10 $\mathrm{min}$, the pellets resuspended in $5 \mathrm{~mL}$ of PBS, mixed with an equal volume of Sepracell-MN (Sepratech Co., Oklahoma City, OK, U.S.A.) and centrifuged at $3700 \times g$ for $10 \mathrm{~min}$. This was followed by washing and lysing of any residual red cells. A total of $3 \times 10^{7}$ neutrophils $(1 \mathrm{~mL})$ were labeled with ${ }^{51} \mathrm{Cr}$, spun, washed, and resuspended to a final concentration of $5 \times$ $10^{5}$ cells $/ \mathrm{mL}$.

Chemotaxis assays were performed in a 48-well microchamber. Buffer alone was used as a negative control and referenced as $0 \%$ activity. Zymosan-activated serum was used as a positive control and considered to be $100 \%$ activity. A single polycarbonate (pore $8 \mu \mathrm{m}$ ) and nitrocellulose filter (pore $3 \mu \mathrm{m}$ ) separated the lower and upper chambers. To each upper well were added $2.5 \times 10^{4}$ neutrophils. The chamber was incubated at $37^{\circ} \mathrm{C}$ in a humidified incubator for $50 \mathrm{~min}$. Cells that penetrated the polycarbonate filter were trapped on the nitrocellulose filter and were counted in a gamma counter (LKB 
Instruments, Gaithersburg, MD, U.S.A.). The chemotactic activities of concentrated BAL fluids were calculated as a percentage of positive controls. All samples were assayed in quadruplicate. The concentration of total protein in BAL fluid was quantified using the Pierce bicinchoninic microtiter technique (14).

Myeloperoxidase assays were performed on whole lung. Homogenized lung tissue from the left lung was prepared in 2 $\mathrm{mL}$ buffer. One hundred microliters of sample was then added to $3 \mathrm{~mL}$ of $50 \mathrm{mM} \mathrm{K}$-phosphate buffer ( $\mathrm{pH} 6.0$ ) with 0.167 $\mathrm{mg} / \mathrm{mL} O$-dianisidine dihydrochloride (concentration $0.3 \mathrm{mg} /$ $\mathrm{mL}$ ) and $5 \times 10^{-4} \mathrm{M}$ hydrogen peroxide. The absorbance of 460-nm visible light was measured for 5 min using the Beckman DU-64 spectrophotometer with kinetic module (Beckman Coulter, Inc., Fullerton, CA, U.S.A.). Standard MPO enzyme (\#M-6908) was purchased from Sigma Chemical (St. Louis, MO, U.S.A.) and was diluted to 2 units (U)/mL where 1 unit MPO activity will reduce $1 \mathrm{fmol}$ peroxide/min. MPO activity (U/g tissue) was calculated as $\left(\mathrm{A}_{460}\right) / 0.025(\mathrm{std}) \times 2 \mathrm{~mL} / \mathrm{g}$ tissue.

Pharmacokinetics. Serum, urine $(0,2,4,8,12,24,36$, and $48 \mathrm{~h})$ and 48 -h BAL samples were collected and volumes recorded for analysis of CC10 concentrations. A competitive ELISA (Claragen, Inc.) was performed using a rabbit polyclonal antihuman urine protein-1 (CC10) antibody (DAKO, Carpinteria, CA, U.S.A.). One hundred microliters of antibody ( $2 \mathrm{mg} / \mathrm{mL}$ stock solution in $0.1 \mathrm{M}$ carbonate/bicarbonate buffer, $\mathrm{pH} 9.5$ ) diluted to 1:2500, was coated onto the wells of a microtiter plate and incubated overnight at room temperature. The coating solution was then removed and wells were blocked for $2 \mathrm{~h}$ at room temperature with 5\% sucrose, 5\% BSA in PBS. A conjugate of rhCC10 and horseradish peroxidase was made using a labeling kit (Pierce Chemical, Rockford, IL, U.S.A.). To each well, $100 \mu \mathrm{L}$ of the CC10 conjugate was mixed 1:1 with standard solution or sample and incubated for $1 \mathrm{~h}$ at room temperature, followed by washing each well three times. A standard HRP enzymatic colorimetric reaction was then developed with OPD substrate (Pierce Chemical Co.) and read at $\mathrm{OD}_{490}$. Standard curves using a set of six rhCC10 calibrators were run with each set of samples. Coefficients of variation were $<15 \%$. All samples were run in duplicate. The quantity of rhCC10 in the urine and the BAL fluid was calculated by multiplying the rhCC10 concentration by the volume of the sample (with total rhCC10 in the urine over the 48-h study period determined by the sum of these values).

Pathologic examination of the lung, both gross and microscopic, was performed on sections of the right lower lobe. A representative cross-section of tissue was submitted for hematoxylin and eosin staining and examined by a pathologist, blinded to the treatment assignment of the animal.

Statistical analyses. Differences between experimental groups were analyzed with one-way ANOVA, with multiple comparison testing used when indicated. Repeated measures ANOVA was performed on longitudinal data. Log transformation was performed when variance was not equal. Results from the pressure-volume curves were analyzed using AUC (area under the curve with the trapezoid rule).

\section{RESULTS}

Pulmonary physiologic results. Pressure-volume curves (deflation limbs) were generated as a measure of physiologic stability of lung and are shown in Figure 1. Pulmonary compliance was significantly different among the study groups ( $p$ $<0.05$, ANOVA). Animals treated with $5 \mathrm{mg} / \mathrm{kg} \mathrm{rhCC} 10$ and $100 \% \mathrm{O}_{2}$ had significantly improved compliance compared with animals who received no drug and were ventilated with $100 \% \mathrm{O}_{2}(p<0.005$, multiple comparison testing) and were comparable to room air control animals. The animals that were ventilated with $100 \% \mathrm{O}_{2}$ and received 25 and $1 \mathrm{mg} / \mathrm{kg}$ of IT rhCC10 also demonstrated improvements in pulmonary compliance compared with animals that were ventilated with $100 \%$ $\mathrm{O}_{2}$ alone, but these improvements did not reach statistical significance.

Significant improvements in oxygenation were also demonstrated in animals exposed to mechanical ventilation and $100 \%$ $\mathrm{O}_{2}$ when $5 \mathrm{mg} / \mathrm{kg}$ rhCC10 was administered. Figure 2 depicts the mean a/A ratios in the different study groups, calculated using the last available arterial blood gas before sacrifice. Significant differences were noted among the five study groups $(p<0.05)$. As expected, control animals ventilated with $100 \%$ $\mathrm{O}_{2}$ had significantly lower a/A ratios compared with control animals ventilated with RA $(p<0.005)$. However, animals

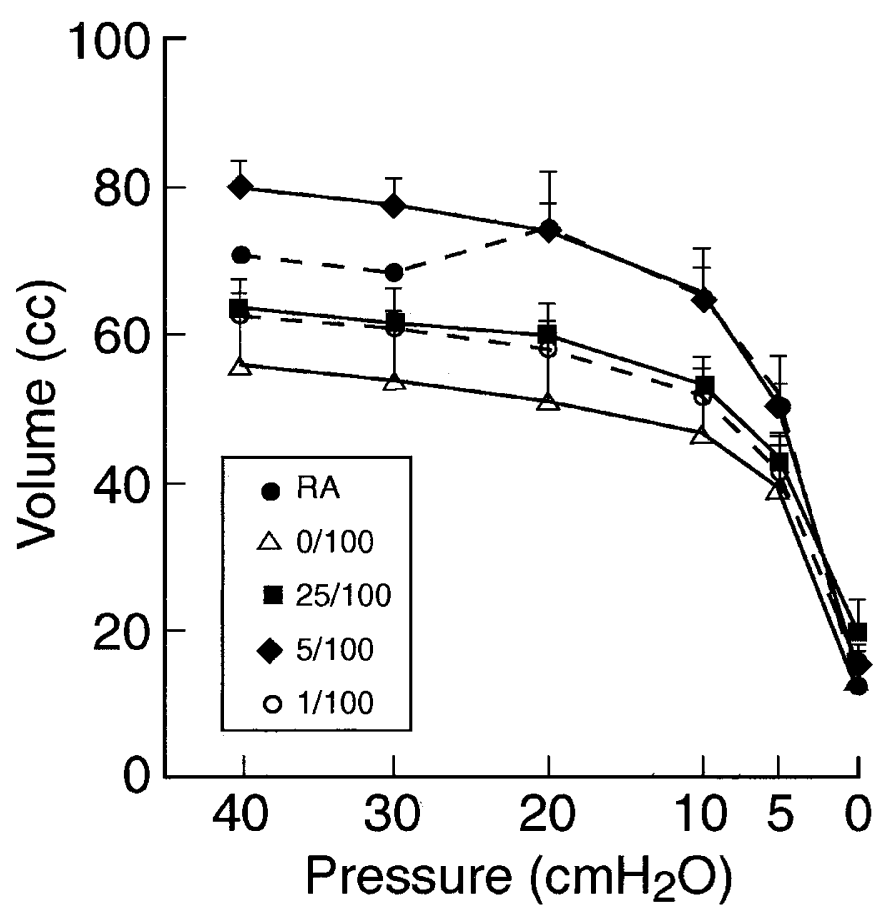

Figure 1. Effect of IT rhCC10 on static pulmonary compliance (deflation limb of pressure volume curve). One- to 3-d-old piglets were mechanically ventilated for $48 \mathrm{~h}$ and studied as follows: ventilated with $21 \%$ oxygen and received IT placebo ( $2 \mathrm{~mL} / \mathrm{kg}$ normal saline) at time 0 ; ventilated with $100 \%$ $\mathrm{O}_{2}$ and received IT placebo at time 0; ventilated with $100 \% \mathrm{O}_{2}$ and received 1,5 , or $25 \mathrm{mg} / \mathrm{kg}$ IT rhCC10. Significant differences were seen among groups (ANOVA, $p<0.05$ ). Animals that received $5 \mathrm{mg} / \mathrm{kg}$ of IT $\mathrm{rhCC} 10$ and were ventilated with $100 \% \mathrm{O}_{2}$, had improved static pulmonary compliance compared with animals that received no drug and were ventilated with $100 \% \mathrm{O}_{2}$ $\left({ }^{*} p<0.005\right)$ or animals who received $1 \mathrm{mg} / \mathrm{kg}$ of IT $\mathrm{rhCC} 10(\# p<0.05)$ and were comparable to RA controls. 


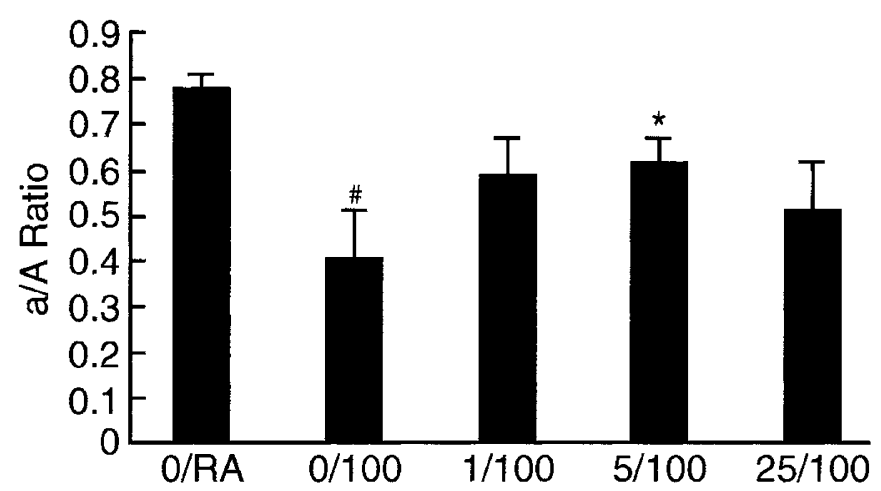

Figure 2. Effect of IT rhCC10 on the arterial/alveolar ratio (a/A ratio) at $48 \mathrm{~h}$. One- to 3-d-old piglets were mechanically ventilated for $48 \mathrm{~h}$ and studied as follows: ventilated with $21 \%$ oxygen and received IT placebo $(2 \mathrm{~mL} / \mathrm{kg}$ normal saline) at time 0 ; ventilated with $100 \% \mathrm{O}_{2}$ and received IT placebo at time 0 ; ventilated with $100 \% \mathrm{O}_{2}$ and received 1,5 , or $25 \mathrm{mg} / \mathrm{kg}$ IT rhCC10. Significant differences were seen among groups (ANOVA, $p<0.05$ ). Animals treated with $5 \mathrm{mg} / \mathrm{kg}$ of IT rhCC10 and ventilated with $100 \% \mathrm{O}_{2}$ had significantly improved oxygenation compared with control animals ventilated with $100 \%$ $\mathrm{O}_{2}\left({ }^{*} p<0.05\right)$ and were comparable to control room air animals. Control animals ventilated with $100 \% \mathrm{O}_{2}$ had decreased a/A ratios relative to room air control animals $(\# p<0.005)$.

that received $5 \mathrm{mg} / \mathrm{kg}$ IT rhCC10 in conjunction with $100 \% \mathrm{O}_{2}$ had significantly improved a/A ratios compared with control animals ventilated with $100 \% \mathrm{O}_{2}(p<0.05)$ and were comparable to RA controls. This would indicate an improvement in overall oxygenation as a result of rhCC10 treatment.

Biochemical assays. NCA is one of the earliest indicators of acute lung injury found in BAL fluid and is representative of one or more inflammatory factors that are chemoattractive or chemokinetic for normal neutrophils (15). As expected, animals ventilated with $100 \% \mathrm{O}_{2}$ demonstrated the highest NCA (Fig. 3). Decreased NCA was found in animals who were ventilated with $100 \% \mathrm{O}_{2}$ and received rhCC10, but the activities did not quite reach statistical significance. Total protein

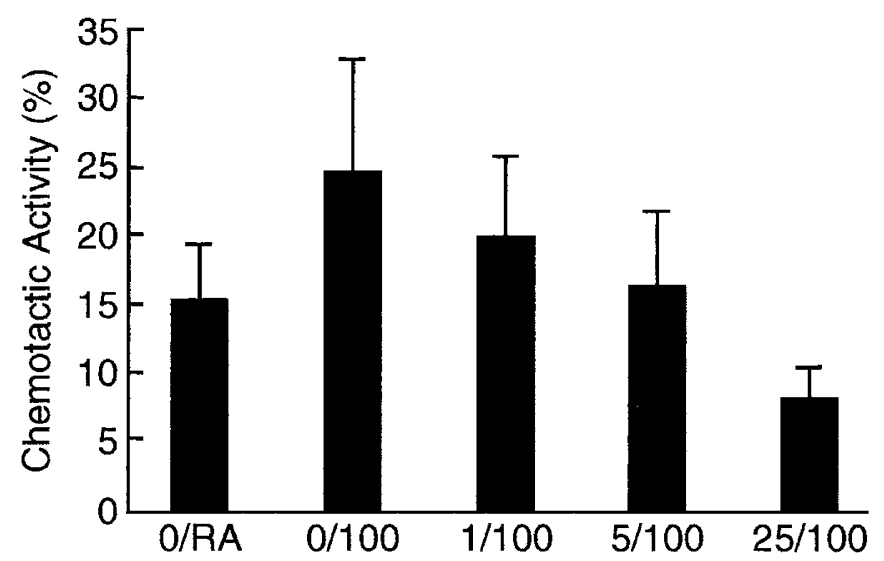

Figure 3. Effect of IT rhCC10 on NCA of BAL fluid, expressed as percentage of positive control (zymosan-activated serum referenced as $100 \%$ and buffer as $0 \%$ ). One- to 3-d-old piglets were mechanically ventilated for $48 \mathrm{~h}$ and studied as follows: ventilated with $21 \%$ oxygen and received IT placebo $(2 \mathrm{~mL} / \mathrm{kg}$ normal saline) at time 0 ; ventilated with $100 \% \mathrm{O}_{2}$ and received IT placebo at time 0 ; ventilated with $100 \% \mathrm{O}_{2}$ and received 1,5 , or $25 \mathrm{mg} / \mathrm{kg}$ IT rhCC10. NCA activity tended to be lower in animals ventilated with $\mathrm{O}_{2}$ and treated with increasing doses of rhCC10 compared with control animals ventilated with $100 \% \mathrm{O}_{2}$ concentration, a measure of macromolecular edema, was also assayed in BAL. As seen in Figure 4, treatment with higher doses of IT rhCC10 also tended to decrease BAL total protein concentration. However, these differences were not significant due to considerable variability of control animals ventilated with $100 \% \mathrm{O}_{2}$. BAL cell counts did not differ among the five study groups. There were no statistically significant differences in MPO activity among the groups (data not shown).

There were no significant differences in blood counts or coagulation studies among experimental groups receiving rhCC10 versus control. Although pathologic examination revealed a degree of baseline atelectasis in most of the lung tissue examined (most likely a preservation artifact), there were no significant differences among groups.

Pharmacokinetics. rhCC10 was not detected in the untreated groups or at baseline in the groups treated with rhCC10 (no cross-reactivity with porcine $\mathrm{CC} 10$ was noted). Figure 5 demonstrates the serum concentration of rhCC10 as a function of time for the three groups that received rhCC10. Peak serum levels of $4-17 \mathrm{~g} / \mathrm{mL}$ (mean, $8.6 \pm 6.1 \mathrm{~g} / \mathrm{mL}$ ) were measured between 2 and $8 \mathrm{~h}$ after rhCC10 administration. The elimination half-life was determined using the linear part of the curve between 4 and $12 \mathrm{~h}$ postadministration using first-order kinetics. The elimination half-life decreased slightly with increasing dose: $11.7 \mathrm{~h}$ for $1 \mathrm{mg} / \mathrm{kg}, 11.0 \mathrm{~h}$ for $5 \mathrm{mg} / \mathrm{kg}$, and $9.6 \mathrm{~h}$ for 25 $\mathrm{mg} / \mathrm{kg}$. rhCC10 appeared in the urine between 8 and $24 \mathrm{~h}$ postadministration and the total rhCC10 that reached the urine over the $48 \mathrm{~h}$ was $<0.5 \%$ of the original dose (data not shown.) rhCC10 persisted in the BAL fluid for $48 \mathrm{~h}$ and up to $3.3 \%$ of the original dose was recovered in the BAL fluid.

\section{DISCUSSION}

This investigation is the first to study the safety and efficacy of IT administration of rhCC10 in the prevention of hyperoxic lung injury. Our data demonstrate the ability of IT rhCC10 to safely minimize acute lung injury in this well-established

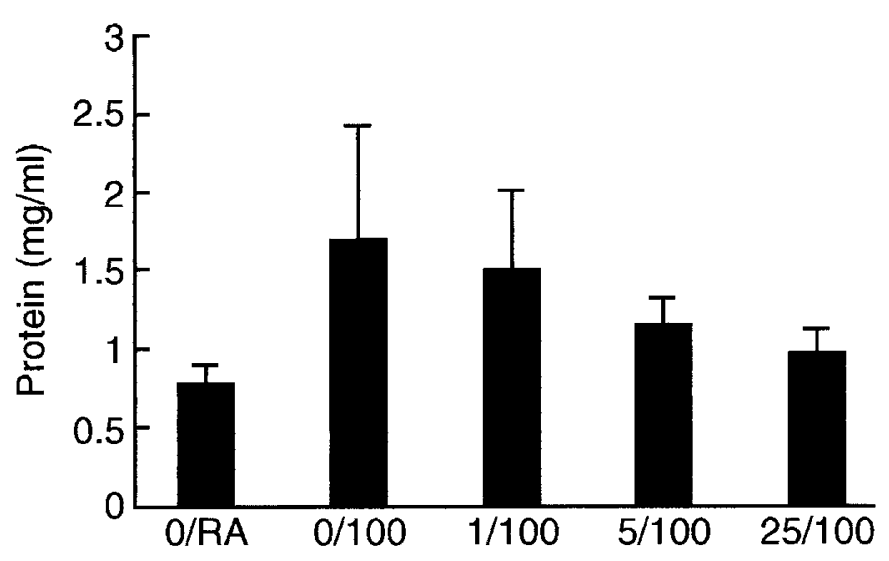

Figure 4. Effect of IT rhCC10 on BAL total protein concentration. One- to 3-d-old piglets were mechanically ventilated for $48 \mathrm{~h}$ and studied as follows: ventilated with $21 \%$ oxygen and received IT placebo ( $2 \mathrm{~mL} / \mathrm{kg}$ normal saline) at time 0 ; ventilated with $100 \% \mathrm{O}_{2}$ and received IT placebo at time 0; ventilated with $100 \% \mathrm{O}_{2}$ and received 1,5 , or $25 \mathrm{mg} / \mathrm{kg}$ IT rhCC10. There was a trend toward decreased BAL total protein concentration in animals ventilated with $100 \% \mathrm{O}_{2}$ and treated with increasing doses of IT rhCC10 compared with animals ventilated with $100 \% \mathrm{O}_{2}$. 


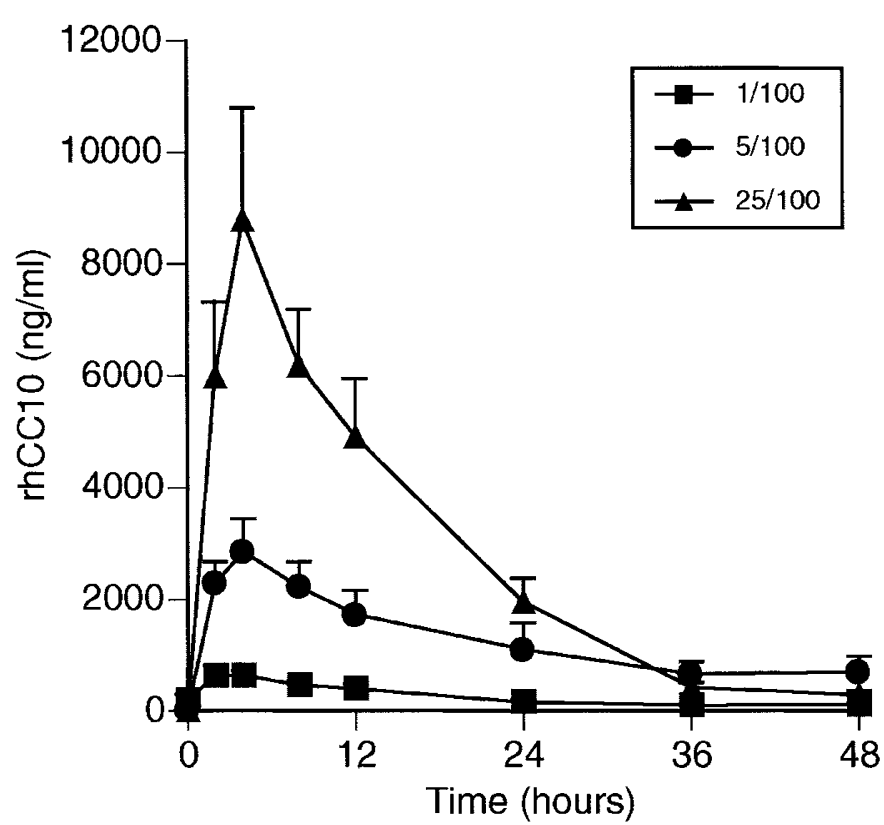

Figure 5. Pharmacokinetics of varying doses of IT rhCC10 in serum. One- to 3 -d-old piglets were given 1,5 , or $25 \mathrm{mg}$ IT rhCC10 and serum samples were obtained at $0,2,4,8,12,24,36$, and $48 \mathrm{~h}$. rhCC10 concentration was measured by a competitive ELISA and data are shown as mean \pm SEM.

newborn animal model. We demonstrated significantly improved lung mechanics and oxygenation in animals ventilated with $100 \% \mathrm{O}_{2}$ for $48 \mathrm{~h}$ and given a single dose of IT rhCC10 compared with control animals ventilated with $100 \% \mathrm{O}_{2}$. It is noteworthy that $5 \mathrm{mg} / \mathrm{kg}$ of IT rhCC10 was able to maintain pulmonary compliance and oxygenation in these hyperoxic animals at values comparable to room air controls.

Although the literature is limited regarding CC10 in the preterm population, the available data suggest an important role for $\mathrm{CC} 10$ in the lung. Preterm infants are known to be deficient in pulmonary CC10 $(10,11,16)$, with levels increasing with advancing gestational age $(10,11)$. Studies have correlated Clara cell protein concentration with lung weight and fetal survival (11), suggesting that CC10 is a potential marker of fetal lung growth (11). Most recently, increased levels of oxidized CC10 in ventilated preterm ( $<29 \mathrm{wk})$ infants were shown to correlate significantly with the development of BPD (12). These clinical studies provided rationale for ongoing clinical trials of supplementation with rhCC10, as well as support for our findings.

Hyperoxia can cause intense pulmonary inflammatory and oxidant injury (17-21), which can ultimately result in decreased oxygenation and pulmonary compliance $(20,22)$. The overall improvement in a/A ratios seen in the animals that received $5 \mathrm{mg} / \mathrm{kg}$ and $100 \%$ oxygen demonstrate the potential ability of rhCC10 to minimize this injury. This may be indicative of a direct effect on the pulmonary vasculature because a/A ratios performed on $100 \%$ oxygen address the shunt compartment only. It is also possible that, had the testing been performed at lower concentrations of oxygen (when both the shunt fraction and low V/Q compartments are addressed), improvements in oxygenation might also have been demonstrated with $1 \mathrm{mg} / \mathrm{kg}$ dosing. These improvements in lung mechanics and oxygenation seen in this study correlate nicely with the findings of Lassus et al. (10), who demonstrated a negative correlation between $\mathrm{CC} 10$ concentration in tracheal aspirate fluid of preterm infants and inspiratory oxygen concentration. Both of these observations may also be the result of the documented anti-inflammatory properties of CC10. CC10 has been shown to inhibit the chemotactic activity of neutrophils, phagocytes (3), monocytes, macrophages (23), and fibroblasts (5). In vitro, CC10 has been demonstrated to block several pathways involved in the generation of secondary mediators of inflammation; specifically the cleavage of arachidonic acid from cell membranes (by inhibiting $\mathrm{SPLA}_{2}$ ) and the IL-2-stimulated release of lymphokines in human peripheral blood lymphocytes (4). In vivo, observations of accelerated mortality and pulmonary inflammation in CC10-deficient mice subjected to hyperoxia (8) further support an anti-inflammatory role of CC10.

Although rhCC10 significantly improved oxygenation and compliance, the reductions in biochemical measures of pulmonary inflammation (including MPO analyses) did not quite reach statistical significance. These findings call into question the hypothesis that the beneficial effects of rhCC10 were due solely to an effect on mitigating inflammation. Given the numerous mechanisms of action of CC10, it is possible that a single dose of $5 \mathrm{mg} / \mathrm{kg}$ rhCC10 may improve pulmonary compliance and oxygenation at $48 \mathrm{~h}$, yet not have long-lasting effects on inflammatory mediators. Dosing in this study was based on studies demonstrating short-term improvement in blood gas values when a single dose of $5 \mathrm{mg} / \mathrm{kg}$ of IT rhCC10 was delivered to preterm lambs in a similar fashion (Pilon A, personal communication). The trend toward decreased inflammation at $48 \mathrm{~h}$ with the higher doses of IT rhCC10, as well as the pharmacokinetic data, suggest that a multiple dosing regimen may be necessary for prolonging any beneficial effects and preventing BPD. In addition, significant variability was seen in both the NCA and the total protein concentrations in control animals ventilated with $100 \% \mathrm{O}_{2}$. This biologic variability and the relatively small sample size may have masked any significant anti-inflammatory effects. We have also begun to look at various inflammatory cytokines in hopes of demonstrating potential anti-inflammatory effects of rhCC10. Although our attempts have been thwarted by the lack of commercially available kits specific for use in pigs, the future development of these assays should help to clarify the anti-inflammatory role for rhCC10 in preterm lung disease.

Another possible explanation for the improvement in lung mechanics and oxygenation demonstrated in this study is the potential effect of rhCC10 on surfactant function $(1,6,24)$. rhCC10 inhibits sPLA $_{2}$ enzymes, which have been shown to mediate hydrolysis of dipalmitoyl phosphatidylcholine, a major component of surfactant $(2,6,25,26)$. sPLA $_{2}$ is also up-regulated and released during inflammatory responses (27), thus rhCC10 may have suppressed its activation or release, thereby indirectly increasing the active surfactant pool size. Support for a role of CC10 in inhibition of surfactant degradation comes from a recent observational study. Patients at high risk for severe endogenous surfactant dysfunction (acute respiratory distress syndrome) who did not develop fulminant 
disease, had significantly higher levels of CC10 in BAL than those who developed acute respiratory distress syndrome (24). Further studies are needed to examine the exact effect of rhCC10 on surfactant function and metabolism in this animal model.

Little is known about the distribution and metabolism of $\mathrm{CC} 10$. Although $\mathrm{CC} 10$ is primarily produced by Clara cells, it is also produced in the pancreas, prostate, and uterine endometrium $(28,29)$. CC10 of prostatic origin is found in semen and is not thought to enter the circulation. The contribution of the pancreas and uterus to the circulating concentration of $\mathrm{CC} 10$ remains unknown. The main source of $\mathrm{CC} 10$ in the circulation is thought to be of pulmonary origin and our results represent the first confirmation that $\mathrm{CC} 10$ within the lungs can enter the circulation and be eliminated in the urine. It is interesting to note, however, that $<3 \%$ of the instilled rhCC 10 was detected in the BAL at $48 \mathrm{~h}$, with even less excreted intact in the urine. The low recovery of rhCC10 in serum, urine, and BAL fluid suggests the possibility of rhCC10 uptake in the lung or other tissue. It is also possible that rhCC10 may have been metabolized or oxidized into a form that was not readily detectable by the assay used in this study. Further study is needed to elucidate the metabolism of IT rhCC10.

IT rhCC10 was well tolerated, with no obvious toxicity observed at the three doses used in this study. Although it might have been prudent to study groups of animals at all three doses of rhCC10 in room air to demonstrate safety of IT rhCC10, we felt that our observations in the current study groups exposed to $100 \%$ oxygen was fairly strong evidence that the protein was safe. There was a trend toward decreased inflammation with higher doses of rhCC10 (Figs. 3 and 4) and there were no obvious signs of rhCC10 toxicity in any of the assays performed. There were no abnormalities in the hematologic parameters measured, with no signs of platelet dysfunction despite reports that $\mathrm{CC} 10$ can inhibit thrombin-induced platelet aggregation $(30,31)$. In vitro, $\mathrm{CC} 10$ has also been described as a potential immunosuppressive agent that could theoretically increase the risk of infection in an already compromised premature infant. No significant change was demonstrated in white blood cell or granulocyte counts. In addition, there was no increased incidence of pulmonary infection on pathologic examination of lung tissue. Whereas previous studies (unpublished data) demonstrated a slight increase in atelectasis in animals who received $25 \mathrm{mg} / \mathrm{kg}$ IT rhCC10 and were then followed for $30 \mathrm{~d}$, significant atelectasis was not apparent in this study.

Because inflammation (32), fibrosis, and an immature lung/ surfactant system have historically been thought to be important in the pathogenesis of BPD (33), it seems logical that lower $\mathrm{CC} 10$ concentrations and activity might correlate with the development of BPD. Although fibrosis may play less of a role in the pathogenesis of the "new" BPD, the relative roles of various insults to the immature lung (surfactant deficiency, oxidant injury, and inflammation) in interfering with the process of alveolarization has yet to be determined. We have demonstrated that IT rhCC10 significantly improves pulmonary compliance and oxygenation in animals ventilated for $48 \mathrm{~h}$ with $100 \% \mathrm{O}_{2}$ and was well tolerated. Although this study examined the safety and efficacy of a single dose of IT rhCC10 on acute lung injury, the findings presented serve to provide the framework for future studies directed at the use of rhCC10 to prevent BPD.

Acknowledgment. The authors thank Dr. James Melby for the development of the CC10 ELISA.

\section{REFERENCES}

1. Guy J, Dhanireddy R, Mukherjee AB 1992 Surfactant-producing rabbit pulmonary alveolar type II cells synthesize and secrete an antiinflammatory protein, uteroglobin. Biochem Biophys Res Commun 189:662-669

2. Levine SW, Butler JD, Schumacher UK, Wightman PD, Mukherjee AB 1986 Uteroglobin inhibits phospholipase activity. Life Sci 38:1813-1819

3. Vasanthakumar G, Manjunath R, Mukherjee AB, Warabi H, Schiffmann E 1988 Inhibition of phagocyte chemotaxis by uteroglobin, an inhibitor of blastocyst rejection. Biochem Pharmacol 37:389-394

4. Dierynck I, Bernard A, Roels H, De Ley M 1996 The human Clara cell protein: biochemical and biological characterisation of a natural immunosuppressor. Mult Scler 1:385-387

5. Lesur O, Bernard A, Arsalane K, Lauwerys R, Begin R, Cantin A, Lane D 1995 Clara cell protein (CC-16) induces a phospholipase A2-mediated inhibition of fibroblast migration in vitro. Am J Respir Crit Care Med 152:290-297

6. Mantile G, Miele L, Cordella-Miele E, Singh G, Katyal SL, Mukherjee AB 1993 Human Clara cell 10-kDa protein is the counterpart of rabbit uteroglobin. J Biol Chem 268:20343-2035

7. Zheng F, Kundu GC, Zhang Z, Ward J, DeMayo F, Mukherjee AB 1999 Uteroglobin is essential in preventing immunoglobulin A nephropathy in mice. Nat Med 5:10181025

8. Johnston CJ, Mango GW, Finkelstein JN, Stripp BR 1997 Altered pulmonary response to hyperoxia in Clara cell secretory protein deficient mice. Am J Respir Cell Mol Biol 17:147-155

9. Dhanireddy R, El-Ali M, Murthy L, Mukherjee AB 1988 Uteroglobin-like protein in premature infants: effect of gestational age. Pediatr Res 23:463A(abstr)

10. Lassus P, Nevalainen TJ, Eskola JU, Andersson S 2000 Clara-cell secretory protein in preterm infants' tracheal aspirates correlates with maturity and increases in infection. Pediatr Pulmonol 30:466-469

11. Bernard A, Thielemans N, Lauwerys R, Langhendries JP, Van Lierde M, Freund MM 1994 Clara cell protein in human amniotic fluid: a potential marker of fetal lung growth. Pediatr Res 36:771-775

12. Ramsay PL, DeMayo FJ, Hegemier SE, Wearden ME, Smith CV, Welty SE 2001 Clara cell secretory protein oxidation and expression in premature infants who develop bronchopulmonary dysplasia. Am J Respir Crit Care Med 164:155-161

13. Robbins CG, Davis JM, Merritt TA, Amirkhanian JD, Sahgal N, Morin III FC, Horowitz S 1995 Combined effects of nitric oxide and hyperoxia on surfactant function and pulmonary inflammation. Am J Physiol 269:L545-L550

14. Smith PK, Krohn RI, Hermanson GT, Mallia AK, Gartner FH, Provenzano MD, Fujimoto EK, Goeke NM, Olson BJ, Klenk DC 1985 Measurement of protein using bicinchoninic acid. Anal Biochem 150:76-85

15. Davis JM, Whitin J 1992 Prophylactic effects of dexamethasone in lung injury caused by hyperoxia and hyperventilation. J Appl Physiol 72:1320-1325

16. Xu P, Hashimoto S, Miyazaki H, Asabe K, Shiraishi S, Sueishi K 1998 Morphometric analysis of the immunohistochemical expression of Clara cell $10-\mathrm{kDa}$ protein and surfactant apoproteins A and B in the developing bronchi and bronchioles of human fetuses and neonates. Virchows Arch 432:17-25

17. Deneke SM, Fanburg BL 1980 Normobaric oxygen toxicity of the lung. N Engl J Med 303:76-86

18. Crapo JD, Barry BE, Foscue HA, Shelburne J 1980 Structural and biochemical changes in rat lungs occurring during exposures to lethal and adaptive doses of oxygen. Am Rev Respir Dis 122:123-143

19. Fox RB, Hoidal JR, Brown DM, Repine JE 1981 Pulmonary inflammation due to oxygen toxicity: involvement of chemotactic factors and polymorphonuclear leukocytes. Am Rev Respir Dis 123:521-523

20. Davis JM, Dickerson B, Metlay L, Penney DP 1991 Differential effects of oxygen and barotrauma on lung injury in the neonatal piglet. Pediatr Pulmonol 10:157-163

21. Keeney SE, Mathews MJ, Haque AK, Schmalstieg FC 1995 Comparison of pulmonary neutrophils in the adult and neonatal rat after hyperoxia. Pediatr Res 38:857-863

22. Arkovitz M, Garcia V, Szabo C, McConnell K, Bove K, Wispe J 1997 Decreased pulmonary compliance is an early indicator of pulmonary oxygen injury. J Surg Res 67:193-198

23. Hayashida S, Harrod KS, Whitsett JA 2000 Regulation and function of CCSP during pulmonary Pseudomonas aeruginosa infection in vivo. Am J Physiol Lung Cell Mol Physiol 279:L452-L459

24. Jorens PG, Sibille Y, Goulding NJ, van Overveld FJ, Herman AG, Bossaert L, De Backer WA, Lauwerys R, Flower RJ, Bernard A 1995 Potential role of Clara cell protein, an endogenous phospholipase A2 inhibitor, in acute lung injury. Eur Respir J 8:1647-1653

25. Duncan JE, Hatch GM, Belik J 1996 Susceptibility of exogenous surfactant to phospholipase A2 degradation. Can J Physiol Pharmacol 74:957-963 
26. Glaser KB 1995 Regulation of phospholipase A2 enzymes: selective inhibitors and their pharmacological potential. Adv Pharmacol 32:31-66

27. Vadas P, Browning J, Edelson J, Pruzanski W 1993 Extracellular phospholipase A2 expression and inflammation: the relationship with associated disease states. J Lipid Mediat 8:1-30

28. Peri A, Cordella-Miele E, Miele L, Mukherjee AB 1993 Tissue-specific expression of the gene coding for human Clara cell $10-\mathrm{kD}$ protein, a phospholipase A2-inhibitory protein. J Clin Invest 92:2099-2109

29. Peri A, Cowan BD, Bhartiya D, Miele L, Nieman LK, Nwaeze IO, Mukherjee AB 1994 Expression of Clara cell 10-kD gene in the human endometrium and it relationship to ovarian menstrual cycle. DNA Cell Biol 13:495-503
30. Manjunath R, Levin SW, Kumaroo KK, Butler JD, Donlon JA, Horne M, Fujita R, Schumacher UK, Mukherjee AB 1987 Inhibition of thrombin-induced platelet aggregation by uteroglobin. Biochem Pharmacol 36:741-746

31. Vostal JG, Mukherjee AB, Miele L, Shulman NR 1989 Novel peptides derived from a region of local homology between uteroglobin and lipocortin-1 inhibit platelet aggregation and secretion. Biochem Biophys Res Commun 165:27-36

32. Groneck P, Speer CP 1995 Inflammatory mediators and bronchopulmonary dysplasia. Arch Dis Child Fetal Neonatal Ed 73:F1-F3

33. Gerdes JS, Yoder MC, Douglas SD, Paul M, Harris MC, Polin RA 1986 Trachea lavage and plasma fibronectin: relationship to respiratory distress syndrome and development of bronchopulmonary dysplasia. J Pediatr 108:601-606 